Japanese Journal of Physiology, 38, 747-751, 1988

\title{
Histochemical Properties of Intrafusal Fibers in the Soleus Muscle of the Aged Rat
}

\author{
Akihiko ISHIHARA \\ College of General Education, University of Tokushima, \\ Tokushima, 770 Japan
}

\begin{abstract}
Summary ATPase reaction profiles of intrafusal fibers in the muscle spindle of the soleus muscle of 135-week-old rats were examined. Nuclear bag $_{1}$ fibers contained an acid- and alkaline-labile form of the enzyme or an acid-labile and alkaline-stabile form, nuclear $\mathrm{bag}_{2}$ fibers contained an acid- and alkaline-stabile form, and nuclear chain fibers contained an acidlabile and alkaline-stabile form. These results indicate that the enzyme histochemical heterogeneity of intrafusal fibers is well-preserved during ageing.
\end{abstract}

Key words: intrafusal muscle fiber, histochemistry, ageing.

Mammalian muscle spindles, which are known to be sensory stretch receptors, contain three types of encapsulated intrafusal muscle fibers, i.e., nuclear bag $_{1}$, nuclear bag $_{2}$, and nuclear chain fibers (BANKs et al., 1977). These fibers can also be distinguished histochemically on the basis of the myosin ATPase reaction: nuclear bag $_{1}$ fibers contain an acid-stabile and base-labile form of the enzyme, nuclear bag $_{2}$ fibers contain an acid- and base-stabile form, and nuclear chain fibers contain an acid-labile and base-stabile form (Ovalle and SMITH, 1972).

Despite a number of studies on age-related changes in histochemical properties of extrafusal muscle fibers (CACCIA et al., 1979; LARSSON and EDSTröm, 1986; AlnaQeeb and GoldsPinK, 1987; EdSTröm and LARSSON, 1987), little is known about the histochemical characteristics of intrafusal muscle fibers in old age. Therefore, this study investigated ATPase reaction in intrafusal muscle fibers of the soleus muscle of aged rats.

Five 135-week-old Wistar female albino rats were used. Under ether anesthesia, the soleus muscle was removed. The tissue was mounted on chucks with compound and quickly frozen in liquid nitrogen. Fresh frozen serial sections of $8 \mu \mathrm{m}$ thickness were cut transversely on a cryostat-microtome at $-20^{\circ} \mathrm{C}$. Sections were stained for ATPase alternately after acid and alkaline preincubation (GUTH

Received for publication July 6, 1988 


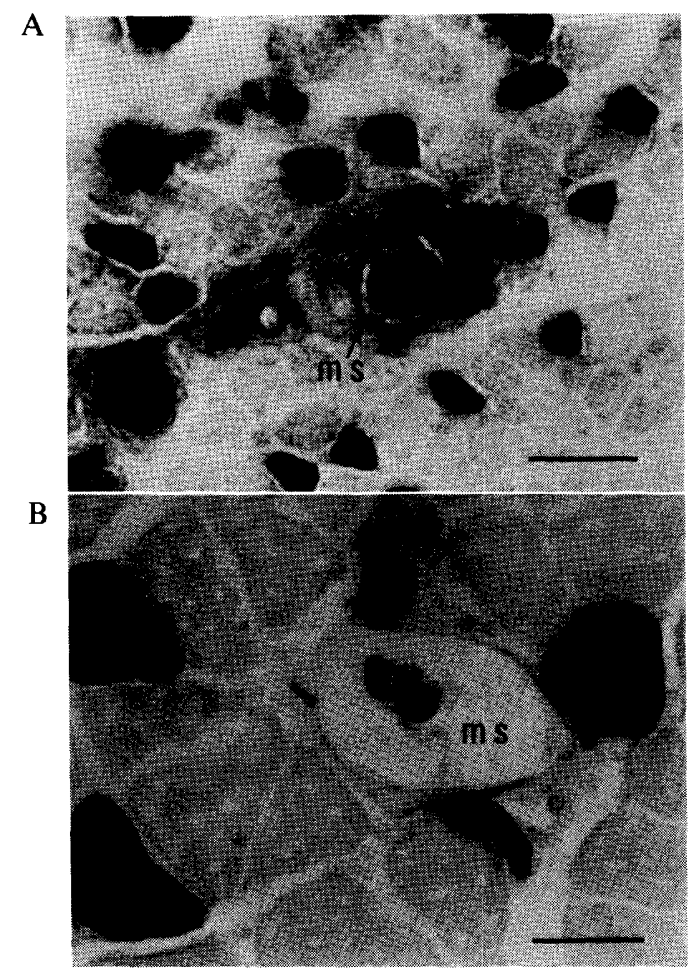

Fig. 1. Intra- and extrafusal fibers in the soleus muscles of 2-week-old (A) and 10week-old rats (B). The sections were stained for ATPase activity after alkaline preincubation. Muscle fibers are distinguished by the enzyme activity. Bar $=40 \mu \mathrm{m}$. ms, muscle spindle.

and Samaha, 1969, 1970). As shown in Fig. 1, intra- and extrafusal fibers in the soleus muscles of young and adult animals were clearly distinguished by low or high enzyme activity. ATPase activity is known to directly correlate with the rate of muscle contraction (BÁRÁNY, 1967).

Of the 27 soleus muscle spindles observed, 25 contained four intrafusal muscle fibers. These fibers could be divided into three different morphological and histochemical types. Two large-diameter fibers in the muscle spindle, which were nuclear bag fibers, consisted of nuclear bag fibers containing an acid- and alkalinelabile form of ATPase or an acid-labile and alkaline-stabile form, and nuclear bag $_{2}$ fibers containing an acid- and alkaline-stabile form. Two small-diameter fibers, which were nuclear chain fibers, contained an acid-labile and alkaline-stabile form of the enzyme. The other two spindles formed two nuclear bag and three nuclear chain fibers (Table 1).

On the other hand, although two types of extrafusal muscle fibers were observed in adulthood (Ariano et al., 1973; Armstrong and Phelps, 1984), all of 
Spindle 1

A

B

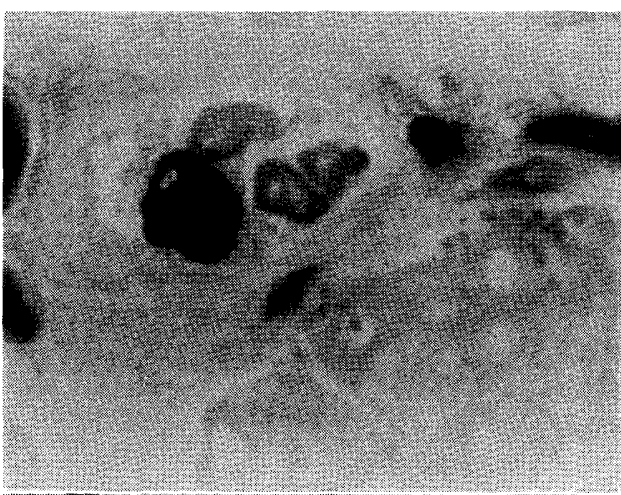

Spindle 2
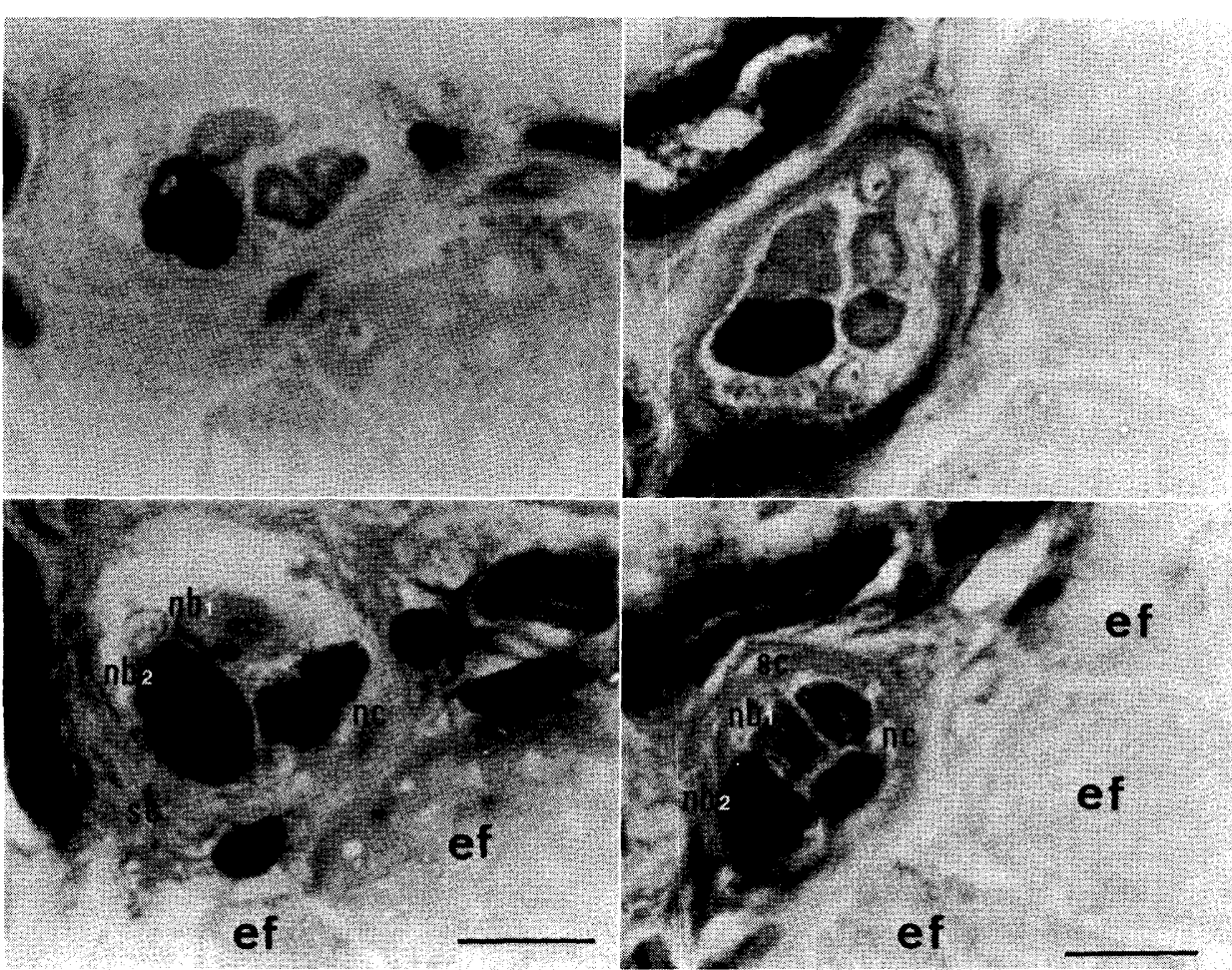

Fig. 2. Serial transverse sections of two muscle spindles in the soleus muscle in a 135week-old rat. The sections were stained for ATPase activity after preincubation in

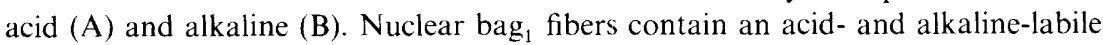
form of the enzyme (spindle 1) or an acid-labile and alkaline-stabile form (spindle 2), nuclear bag $\mathrm{g}_{2}$ fibers contain an acid- and alkaline-stabile form, and nuclear chain fibers contain an acid-labile and alkaline-stabile form. Extrafusal muscle fibers are unreactive after either acid and alkaline preincubation. Bar $=20 \mu \mathrm{m} . \mathrm{nb}_{1}$, nuclear bag $_{1}$ fiber; $\mathrm{nb}_{2}$, nuclear bag $\mathrm{g}_{2}$ fiber; nc, nuclear chain fiber; ef, extrafusal fiber; sc, spindle capsule.

the extrafusal muscle fibers in the soleus muscle of aged rats showed a dedifferentiation pattern of ATPase reaction, namely the enzyme was both acid-and alkaline-labile (Fig. 2).

In this study, intrafusal fibers of the soleus muscle in old age could be divided into three types according to the differences in ATPase activity. This indicates differences of the enzyme activity in the ageing process between intrafusal and extrafusal muscle fibers. Various enzyme activities in extrafusal muscle fibers markedly decrease with ageing (BASS et al., 1975; HANSFORD and CASTRO, 1982). However, the enzyme activities of intrafusal muscle fibers were well-preserved during ageing. In light of the neuromuscular innervation pattern, these findings 
Table 1. Numbers and ATPase staining reactions of intrafusal fibers in 27 soleus muscle spindles of 135 -week-old rats.

\begin{tabular}{|c|c|c|c|c|c|c|}
\hline \multirow{2}{*}{$\begin{array}{l}\text { Number of } \\
\text { spindles }\end{array}$} & \multicolumn{3}{|c|}{$\begin{array}{c}\text { Number of } \\
\text { fibers per spindle }\end{array}$} & & \multicolumn{2}{|c|}{ ATPase reaction } \\
\hline & $\mathrm{Nb}_{1}$ & $\mathrm{Nb}_{2}$ & $\mathrm{Nc}$ & & Acid & Alkaline \\
\hline 22 & 1 & 1 & 2 & $\begin{array}{l}\mathrm{Nb}_{1}: \\
\mathrm{Nb}_{2}: \\
\mathrm{Nc}:\end{array}$ & $\begin{array}{l}\text { labile } \\
\text { stabile } \\
\text { labile }\end{array}$ & $\begin{array}{l}\text { labile } \\
\text { stabile } \\
\text { stabile }\end{array}$ \\
\hline 3 & 1 & 1 & 2 & $\begin{array}{l}\mathrm{Nb}_{1}: \\
\mathrm{Nb}_{2}: \\
\mathrm{Nc}:\end{array}$ & $\begin{array}{l}\text { labile } \\
\text { stabile } \\
\text { labile }\end{array}$ & $\begin{array}{l}\text { stabile } \\
\text { stabile } \\
\text { stabile }\end{array}$ \\
\hline 2 & 1 & 1 & 3 & $\begin{array}{l}\mathrm{Nb}_{1}: \\
\mathrm{Nb}_{2}: \\
\mathrm{Nc}:\end{array}$ & $\begin{array}{l}\text { labile } \\
\text { stabile } \\
\text { labile }\end{array}$ & $\begin{array}{l}\text { labile } \\
\text { stabile } \\
\text { stabile }\end{array}$ \\
\hline
\end{tabular}

$\mathrm{Nb}_{1}$, nuclear bag fiber; $\mathrm{Nb}_{2}$, nuclear bag $\mathrm{g}_{2}$ fiber; $\mathrm{Nc}$, nuclear chain fiber.

support the observations that alpha-motoneurons, which innervate extrafusal muscle fibers, tend to show lower enzyme activity with ageing, whereas gammamotoneurons innervating intrafusal muscle fibers maintain normal enzyme activity in old age (IsHiHARA et al., 1987; IsHIHARA and ARAKI, 1988).

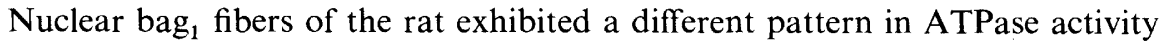
from those of other species (Ovalle and Smith, 1972; Johnson and Ovalle, 1986), whereas this study showed that nuclear bag ${ }_{1}$ fibers are an acid- and alkaline-labile form of the enzyme or an acid-labile and alkaline-stabile form. It seems reasonable to assume that these differences are related to the differences in motor innervation and regulation. However, further investigations are needed to elucidate speciesspecificity in the enzyme activity of intrafusal muscle fibers.

\section{REFERENCES}

Alnaqeeb, M. A. and Goldspink, G. (1987) Changes in fibre type, number and diameter in developing and ageing skeletal muscle. J. Anat., 153: 31-45.

Ariano, M. A., Armstrong, R. B., and Edgerton, V. R. (1973) Hindlimb muscle fiber populations of five mammals. J. Histochem. Cytochem., 21: 51-55.

Armstrong, R. B. and Phelps, R. O. (1984) Muscle fiber type composition of the rat hindlimb. Am. J. Anat., 171: 259-272.

Banks, R. W., Harker, D. W., and Stacey, M. J. (1977) A study of mammalian intrafusal muscle fibers using a combined histochemical and ultrastructural technique. J. Anat., 123: $783-796$.

BÁrÁNY, M. (1967) ATPase activity of myosin correlated with speed of muscle shortening. J. Gen. Physiol., 50: 197-218.

Bass, A., Gutmann, E., and Hanzlíková, V. (1975) Biochemical and histochemical 
changes in energy supply-enzyme pattern of muscles of the rat during old age. Gerontologia, 21: 31-45.

Caccia, M. R., Harris, J. B., and Johnson, M. A. (1979) Morphology and physiology of skeletal muscle in ageing rodents. Muscle Nerve, 2: 202-212.

EDSTRÖM, L. and LARSSON, L. (1987) Effects of age on contractile and enzymehistochemical properties of fast- and slow-twitch single motor units in the rat. $J$. Physiol. (Lond.), 392: 129-145.

Guth, L. and Samaha, F. J. (1969) Qualitative differences between actomyosin ATPase of slow and fast mammalian muscle. Exp. Neurol., 25: 138-152.

Guth, L. and Samaha, F. J. (1970) Procedure for the histochemical demonstration of actomyosin ATPase. Exp. Neurol., 28: 365-367.

HANSFORD, R. G. and CASTRO, F. (1982) Age-linked changes in the activity of enzymes of the tricarboxylate cycle and lipid oxidation, and of carnitine content, in muscles of the rat. Mech. Ageing Dev., 19: 191-201.

IsHIHARA, A. and ARAKI, H. (1988) Effects of age on the number and histochemical properties of muscle fibers and motoneurons in the rat extensor digitorum longus muscle. Mech. Ageing Dev., in press.

Ishihara, A., NaITOH, H., and Katsuta, S. (1987) Effects of ageing on the total number of muscle fibers and motoneurons of the tibialis anterior and soleus muscles in the rat. Brain Res., 435: 355-358.

Johnson, M. I. and OvalLE, W. K. (1986) A comparative study of muscle spindles in slow and fast neonatal muscles of normal and dystrophic mice. Am. J. Anat., 175: 413-427.

LARSSON, L. and EDSTröm, L. (1986) Effects of age on enzyme-histochemical fibre spectra and contractile properties of fast-and slow-twitch skeletal muscles in the rat. J. Neurol. Sci., 76: 69-89.

Ovalle, W. K. and Smith, R. S. (1972) Histochemical identification of three types of intrafusal muscle fibers in the cat and monkey based on the myosin ATPase reaction. Can. J. Physiol. Pharmacol., 50: 195-202. 